Journal of Contemporary Eastern Asia, Volume 9, No.1: 1-21

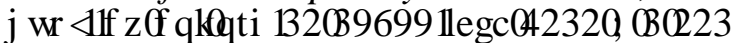

\title{
Politics as usual? De-equalizing rhetoric of political parties on the World Wide Web
}

\author{
Carol Soon ${ }^{*}$
}

With its widespread adoption, the Internet has been looked upon as an agent of change which will shape governance and citizen participation. Mobilization and equalization theories posit that the Internet levels the political playing field by enabling marginalized political groups to overcome barriers such as costs and state control of mass media. This study critically investigates the legitimacy of technologically deterministic claims in a case study analysis of Singapore. In spite of Singapore's recognized success in harnessing information communication technologies for economic development, the democratizing effects of the Internet have been limited. The method adopted for this paper is two-prong. First, through a case study analysis of the media landscape in Singapore, the paper elucidates on the government's effective regulation strategy which results in multifarious effects. Second, this paper uses content analysis and structural analysis of party websites to examine how major and minor political parties in Singapore use Internet technology to disseminate their views and engage with citizens.. The findings clearly suggest that the extent to which the Internet can be used as a tool to engender change hinges on not only political culture and the media regulatory landscape, but also on how political parties frame their identities and utilize structural features embedded in Internet technology. In the case of Singapore's political parties, instead of utilizing Internet technologies to challenge the established status quo, party rhetoric on the World Wide Web engenders a de-equalizing effect that normalizes and stabilizes existing power relations.

\section{Politics as usual?}

Existing studies concerning information communication technologies and political participation have addressed how the technological features of the Internet have enabled different political parties and marginalized groups to further their agendas, mobilize voters and generate political discourse. As the literature review will reveal, a main theme is how the Internet serves as a leveling tool which equalizes power relations among different entities. There appears to be few studies that examine if and how the inherent qualities of party websites may compromise the Internet's democratizing potential and lead to de-equalizing effects. It is often stated in the literature that websites have the potential to act as mouthpieces and mobilization tools for organizations. Using Singapore as a case study due to its paradoxical state of affairs, this paper examines how different political parties in Singapore use the Internet to communicate to the general public - both in terms of party discourse and structural features. In their study of political websites, Ward, Gibson and Nixon (2003) explain that political websites function as a channel for party administration, campaigning, participation and internal organization, and Resnick (1997) states that websites are often produced with the intention of presenting an

\footnotetext{
* Doctoral candidate, Communications and New Media Programme, Faculty of Arts and Social Sciences, National University of Singapore, email: wtsoon@nus.ed.sg.
} 
organization's coherent position, as well as to inform, influence and persuade site visitors. In line with these ideas, the Internet offers possibilities for Singapore political parties to circumvent existing media curtailments and advocate their political causes and garner greater support from the citizenry through their websites. This study thus poses these questions: How do political parties frame their identities on the World Wide Web? What are the key political concepts advocated and how are they framed by each political party? To what extent do political parties deploy structural features in their websites? Aside from examining these questions through an examination of the existing literature, this paper establishes that traditional technologically deterministic rhetoric is questionable and a more nuanced approach is necessary for the study of the Internet's mobilizing potential, especially in authoritative regimes with a history of media regulation.

\section{Mobilizing participation and equalizing opportunities}

The vision of a networked society described by Castells (2004) stems from the interconnection of global politics and economics made possible by Internet technologies. With the growing proliferation of personal, organizational and party websites, political communication scholars have asserted that the World Wide Web potentially provides an viable alternative space for individuals and marginalized groups to circumvent offline media regulations and engage in discourse with one another. Social movement theorists lauded the capabilities of the Internet in fostering awareness and participation by disparate individuals in movements stemming from political, social and economic grievances across transnational boundaries (Della Porter and Diani, 2006; Diani, 2000; Polletta and Jasper, 2001). It is evident from existing literature that most of the technologically deterministic or utopian views stem from the inherent characteristics of the Internet which make it a non-hierarchical, interactive and global medium (Porter, 1997; Rodan, 1998; Shapiro, 1999). A common thread of argument is that although the Internet is a more evolutionary than revolutionary medium, what sets it apart from traditional media is it accords to governments, business organizations and individuals unprecedented control that helps them to overcome both spatial and time constraints. Media consumers have an unprecedented level of information control as they can now actively seek out and select information that appeals to their diverse interests and are relevant to their needs (Ward, Gibson and Nixon, 2003). For instance, in traditional mass media, content is mainly disseminated in a top-down fashion, from governments to the citizenry, from media owners to audiences (Jenkins, 2006). However, in the age of Web 2.0, Jenkins describes how media users produce and share media content, thereby posing a challenge to authoritative channels of linear information dissemination.

Copious literature from various academic disciplines such as political science, media studies and sociology have addressed the implications of Internet use in the political sphere and enriched theoretical understanding concerning the mobilizing effects of the Internet - specifically how the technology acts as a mediator which links political parties and marginalized groups to the electorate or citizenry and how it serves as a public sphere in facilitating civic discourse and promoting political participation (e.g. Poster, 1997; Schwartz, 1996; Shapiro, 1999). Sociologists Ho, Baber and Khondker (2002) explain 
that through use of the Internet, different public interest groups and civil society organizations are able to recruit members, propagate their views to a larger audience and challenge existing rules and regulations. The Internet also plays the role of an intermediary through which citizens can gain access to the government, engage in various political actions, learn about issues or candidates, and organize political action (Bimber, 1999; Schneider and Foot, 2002; Liu, 1999; Norris, 2000). Essentially, mobilizing perspectives posit that the Internet leads to democracy and empowerment by reducing barriers to civic engagement, leveling financial obstacles and increasing the opportunities for political debate and disseminating information in a world where the use of technology is becoming more ubiquitous (Anderson and Cornfield, 2003; Dertouzos, 1997; Negroponte, 1995). Existing research have also addressed how the technological features and affordances embedded in Internet technologies facilitate political mobilization and engagement. For instance, hyperlinks are perceived as networking tools (Garrido and Halavais, 2003; Park, 2003; Roger and Marres, 2000; Soon and Kluver, 2007). In their analysis of 13 presidential campaign websites during the 2000 U.S. presidential election, Schneider and Foot (2002) found that information gathering and persuasion was the most frequently supported political action by the online structure. Based on focus group findings, Stromer-Galley and Foot (2002) concluded that Internet users felt empowered by the medium as they explored presidential candidates' sites. Users also claimed that the Internet provides them with not just greater choice, but also greater control over the information to which they expose themselves.

Norris (2002) states that political participation has been witnessing an evolution and diversification in terms of the agencies, the repertoires of actions commonly used for political expression, and the targets whom participants seek to influence. The openness and access to the World Wide Web thus provide political parties, especially fringe and marginalized parties, with opportunities to overcome regulatory and financial limitations, and disseminate information to the public, raise funds, recruit members, and to enhance citizens' participation in general. Margolis, Resnick and Levy (2003) posit that the lack of editorial control and the relative low cost of creating and maintaining a website enables minor political organizations to establish a platform for their views more easily than in the mainstream media and reach a potentially large audience. Thus, the Internet helps to level the electoral playing field by allowing smaller parties to bypass traditional mainstream media and gain a presence in cyberspace alongside their major counterparts (Gibson and Ward, 1998). The election campaigns of individual candidates also benefit from the increased opportunities afforded to them by the Internet in terms of canvassing for support and funds, one example being Democrat Howard Dean during the 2004 election campaign in the U.S who has been lauded for redefining electoral campaigning (Tremayne, 2007). In Asia, prominent political figures such as the ex-Prime Minister of Malaysia, Dr. Mahathir Mohamad (see http://chedet.co.cc/chedetblog/), are using the Internet as a means to voice their criticisms concerning government policies and engaging in dialogues with members of the public.

Similar claims concerning the mobilizing and equalizing effects of the Internet have been made by scholars who examined cyber-activism and how the Internet expands existing social movement repertoires to engender social or political change (Gurak and Logie, 2003; Vegh, 2003). In Stein's (2007) analysis of Internet use by six social movement organizations in the U.S., it was found that the Internet was most frequently 
used to describe and explain specific campaigns and how to contribute to them. Other activities carried out through the Internet included distributing urgent action alerts, planning local, national and international actions online, and posting calendars of events. The literature review points to a promising era of equal, or more equal political participation heralded by new communication technologies.

However, scholars who adopt a more moderate stance towards the impact of Internet have described the reinforcing nature of communication afforded by the same technologies. In contrast to the above studies, a common thesis in the studies of these scholars is that a process of self-selection typically occurs in Internet users which reinforces existing ideological positions, thereby resulting in politics as usual. This is because people read, seek information and participate in discussions that are relevant to their own interests and beliefs (Davis and Owen, 1998; Hill and Hughes, 1998; Murdock and Golding, 1989). Echoing the users and gratifications theory, these scholars found that different individuals seek different sources and content when exposed to a variety of media outlets. Users then undergo a self-selection process based on their different predispositions and needs, and they actively and consciously exercise choice and selection. In Hill and Hughes' (1998) study on how people use the Internet politically, they found that most activists do not seek information radically different from others in their normal environment, they simply seek more. The Internet is therefore used merely as an extension of the more common forms of media. Hill and Hughes also examined the content and format of discourse in chat rooms and concluded that chat rooms have a limited impact on promoting deliberative discourse because participants typically sought out those who shared a similar ideology. This resulted in less recruitment and limited the democratizing effects of online political discourse. A study by Paolino and Shaw (2003) also supported the reinforcement theory as their findings suggested that the Internet's value as an "outsider" presidential candidate's tool depends on existing political preferences and the predispositions of voters who have access to campaign websites.

Rejecting linear perspectives which assume the Internet's hypodermic effect on political mobilization, other scholars have addressed the mitigating role of political culture and economy. Addressing the lack of research beyond North America and Western European countries which have strong democratic traditions, Kluver and Banerjee (2005) examined how the use of Internet by new political participants can effectively harness the Internet for mobilization in nine Asian countries, including China, Malaysia and Singapore. Three critical variables - political culture, regulation of Internet content and access to technology - were found to mitigate the democratizing impact of the Internet. Their findings support an earlier analysis by Abbott (2001) which examined Internet adoption in China and Malaysia. Abbott found that the digital divide between the haves and have-nots was the greatest limitation to the emancipatory potential of the Internet. Given the longstanding tradition of media control in Singapore, questions on how political regulation and censorship affect the role of the Internet as a mobilization agent have been raised. The next section reviews government policies and developments of the media regulatory landscape in Singapore, and sets the context for the investigation of the research questions. 


\section{Media Regulation de-equalizing opportunities}

Together with Hong Kong, South Korea and Taiwan, Singapore is known as one of the four successful Tiger economies (Koh and Poh, 2005). In their analysis of the critical role science and technology policy plays in an economy's transition from an industrial economy to an innovation-based economy, Koh and Poh (2005) focused on the cases of Korea and Singapore to demonstrate how developing nations make tremendous progress in their economies by focusing on delivering strategic technology and innovation policies to advance the technological sophistication of their industries. In the 1990s, in order to increase the economic viability of the small nation-state in the international marketplace, the government embarked on a strategy that transformed the island-state into a global infocomm capital that trades in ideas rather than commodities. The success of such initiatives such as the Singapore IT2000 Masterplan and Infocomm 21 Strategy was clearly evident from the sharp increase of Internet penetration and broadband use among the populace. By 2006, home computer penetration among surveyed households reached $78 \%$, with $38 \%$ of the households having access to two or more computers, with $71 \%$ of households having Internet access (Infocomm Development Authority of Singapore, Annual Survey on Infocomm Usage in Households and by Individuals for 2006, 2007). However, in spite of high IT penetration and successful government initiatives to promote an e-inclusive society, the use of the Internet as a democratization tool has been limited by stringent regulatory controls that govern online discourse and website content (Kalathil and Boas, 2003; Rodan, 1998, 2003). To understand this apparent paradox, I will briefly discuss the historical and regulatory developments that have shaped the dynamics behind media governance and use in Singapore.

Since the initial days of post colonialization, mass media in Singapore has played an important role in supporting nation building. Government control and deployment of mass media to cultivate and disseminate hegemonic views and values were justified on the grounds of building social cohesion among the citizenry. The public service monopoly on broadcasting was intended to both protect and promote national culture and identity (Banerjee, 2002). Traditional media were regulated through a myriad of laws such as the Broadcasting Act, the Newspaper and Printing Presses Act, Undesirable Publications Act and Public Entertainment and Meetings Act. Such control spilled over to the cyberspace when Internet regulation came under the jurisdiction of the Media Development Authority (MDA) in the 1990s. The vulnerability of the state, given its geographical location, diverse ethnic and social makeup, are the main reasons given by the government to curtail the expression of political opinions on the Internet. According to Lessig (1999), there are four constraints or regulators that regulate the Internet and limit its democratizing potential, and they are: the law, norms (social and/or cultural), market (price) and architecture (the nature or structure of the product). In Singapore's context, the law is by far one of the more effective forms of regulating usage of the Internet as it operates in two ways. Firstly, by stipulating how an individual or an organization should behave and stating the punishment for deviation, the law is operating on a direct level. Secondly, the law also operates in an indirect way when it modifies another structure of constraints.

Under the Media Development Authority (MDA), the regulation of the Internet is purported to be essential, not to stop religious and political bodies from setting up 
websites, but to promote accountability among users by ensuring that content providers are responsible for what they say. Regulations such as the Internet Code of Practice and the Class License Scheme were put in place to regulate discourse in cyberspace and to promote accountability on the part of content providers. The government's control and regulation of the Internet was also evident during election periods. In August 2001, the government amended the Parliamentary Elections Act to prohibit non-party political websites from hyperlinking to websites that campaign for any party or candidate during election time. The use of audio files and podcasts by political parties was also banned during the last election in 2006, thus further limiting the usage of Internet technologies by political groups. Regulation through the law inadvertently led to a second layer of regulation, that of norms in the society, as it dampened Singaporeans' willingness to go online and voice their opinions or views. For instance, such reluctance was clearly manifested during the aftermath of the fateha.com incident. Fateha.com was a website that was established in the year 2000 and served as the mouthpiece of the Malay community, one of the four main ethnic groups in Singapore. The editor of fateha.com was charged with criminal defamation because of three articles that he posted on the web site in 2001 which questioned the ability of Malay members of parliament to represent the interests of the local Malay community. Following the editor's arrest, the government ordered fateha.com to register as a political website with the MDA under the Internet Class License Scheme. The website ceased its operations soon after this. The tough measures taken by the government drew sharp criticisms from some members of the public who argued that such control on free speech would further stifle creativity in online expression and debate, as well as instill fear and anxiety among the Internet community (Tan, 2002). Several other incidents demonstrated the government's policing and control of the Internet and led to the closures of certain sites, such as the online forum set up by the Think Centre, a high-profile non-governmental organization that champions free speech and human rights (Gomez, 2002). The direct and indirect dependence of Singaporeans on the state for various resources, their vulnerability to surveillance and the possibility of political persecution undermine the willingness and ability of groups and individuals to combat the government's strict measures adopted to regulate the Internet (Rodan, 2003).

When governmental laws and regulations limit the ease with which the public may access information, limit the types of information available, and impose penalties for the dispersal of information, the potential for political parties to benefit from the use of Internet technology is constrained and the political opportunities the Internet presents are de-equalized.

The following section details the method for the study of how major and marginalized political parties frame their party discourse and utilize website structural features.

\section{Method}

For the purpose of this study, the units of analysis are websites belonging to major political parties in Singapore. The sample comprises the parties whose members were elected into the government and they include the People's Action Party (PAP, at 
http://www.pap.org.sg/), Workers' Party (WP, at http://www.wp.org.sg/) and the Singapore Democratic Alliance (SDA, at http://www.spp.org.sg/SDA\%20main\%20new \%201.htm). The PAP came into power when Singapore became an independent state in 1965 and has held the majority of seats in the government since that time. The WP is the only opposition party that was set up during the pre-independence period and has active since 1957. Formed in 2001, the SDA, which comprises four opposition parties (the National Solidarity Party, Singapore People's Party, Singapore Malay National Organization and Singapore Justice Party), was established to provide opposition parties greater possibilities to be successful in larger election wards during elections. The last elections in 2006 gave the PAP 82 out of 84 seats in the parliament, with WP and SDA holding one seat each.

Coding and themes identification were used to extract dominant and recurring themes from the three political parties' websites. Through open coding, recurring concepts were retrieved and organized. Coding, in essence, constitutes a variety of approaches to and ways of organizing qualitative data and linking different parts of the data together (Coffey and Atkinson, 1996). Through this process, useful links (both similarities and differences) among the framing techniques of the three political parties were extracted. Themes identification was used to extract critical concepts and patterns which can be used to build and support theoretical models (Ryan and Bernard, 2003). The dual processes of coding and themes identification helped to exhaust the search for political themes promoted by the three parties. Second, referential content analysis was used to explore the context of usage of the key codes and concepts.

To examine the structural similarities and differences among the three political websites, we adapted the coding scheme developed by Gibson and Ward (2003) in their study of Australian parties' use of the World Wide Web. The websites will be assessed at four levels of website functionality - (i) transparency and information provision, (ii) interactivity, (iii) networking, and (iv) presentation and delivery. By analyzing both party discourse and the structural features of party websites, this study identified similar and dissimilar references and concepts, as well uncovered patterns in the parties' political discourse and relationships among the three parties.

\section{Findings}

From the themes that emerged from the analysis, it became evident that there are three distinct components that shape the narrative structure of Singapore political party discourse. These three components are: (a) role of the party, (b) party performance, and (c) inter-party differences.

\section{The ruling patriarch, a political alternative, and a unified front}

The themes that emerged from the data suggest that the three political parties tell very different stories and adopt exclusive framing strategies in their party website discourse. The ruling party, the PAP, sees itself as performing three critical roles - that of a leader of the nation-state, a provider for the citizenry and a patriarch. The PAP's self-identity as the nation's builder was established in post-colonial Singapore when the survival of the 
nation-state was still in question. The role of the PAP as 'leader of the nation-state' stems from that time and its self-described function as a warrior, defending and "fighting for a young country's independence", as well as being "dedicated to the service of our nation and to the advancement of the well-being of our people." In addition to assuming the identity of nation builder, the PAP also claims the role of a protector, one that preserves and protects Singapore's sovereignty. Another dominant meta-theme that emerged from the data is that of the PAP being a provider for the citizenry, reflected by recurring themes manifested in paternalistic tones, e.g. PAP's proven track record of deliverables, its consistency in solving every citizen's problems and improving the lives of Singaporeans by assuring all of equal opportunities. Table 1 lists some of the instances of the meta-theme of PAP as the citizens' provider from their website. Not only does the PAP claim to look after every aspect of Singaporeans' lives, it also assumes the role of a patriarch who instills positive values like discipline and self-reliance in the citizenry.

Table 1: PAP as the provider

\begin{tabular}{|c|l|l|}
\hline No. & Section of Website & Excerpt \\
\hline 1.1 & About PAP & $\begin{array}{l}\text { "..to build a strong united Party, to create a vibrant, just and } \\
\text { equal society... so that every citizen, regardless of race, } \\
\text { language or religion, can enjoy a full and happy life." }\end{array}$ \\
\hline 1.2 & Our Constitution & $\begin{array}{l}\text { "To safeguard the freedom, and advance the well-being, of } \\
\text { Singaporeans through representative and democratic } \\
\text { government." } \\
\text { "To build a dynamic society which is disciplined and self } \\
\text { reliant..." }\end{array}$ \\
\hline 1.3 & $\begin{array}{l}\text { News and Stories - General } \\
\text { Articles }\end{array}$ & $\begin{array}{l}\text { "New MPs improving lives of residents with new amenities } \\
\text { and facilities..." } \\
\text { "The PAP government is tackling rising costs." }\end{array}$ \\
\hline 1.4 & News and Stories - Press Releases & $\begin{array}{l}\text { "We deliver on our promise to create a better future..." } \\
\text { "While we continue to pay attention to the needs of } \\
\text { Singaporeans of all ages..." }\end{array}$ \\
\hline
\end{tabular}

Source: http://www.pap.org.sg/

Economic progress, racial and religious harmony and high literacy rates are examples of some of the advances that the PAP claims to have delivered over the years (see Table 1). Site visitors are constantly reminded of how the PAP has improved the lives of Singaporeans by effectively providing for the people and ensuring their basic needs are met (e.g. through job creation and creating modern living facilities). In fact, its claimed track record of deliverables is used by the party as a form of inter-party comparison where it sets itself apart from the opposition parties, as evident in this instance:

Mr Lee Kuan Yew, the first PM, set the tone by campaigning on practical issues which have a real impact on people's lives, rather than abstract platforms. (About PAP > Party Progress) 
Although both the PAP and the WP share a similar narrative structure, the themes analysis reveals that the WP frames its identity very differently. WP presents itself as a credible opposition party, a representative of the working class and an alternative political voice. A recurring theme that emerges from the analysis is that the WP represents the people and seeks to return power to the citizenry. The WP talks about itself as being a credible opposition party that "will help drive the country forward in progress by offering constructive and responsible alternative voices in Parliament." Its key role as an opposition party is to provide an alternative political philosophy and an alternative political voice to that of the PAP's.

\begin{abstract}
We will ensure that the government is democratically accountable and no citizen is denied the free exercise of his or her rights to political participation. We act in consultation and partnership with all citizens. We propose to reverse the PAP's elitist structure so that the flow of decision making and implementation is from the citizens to the government. (Our Beliefs > Vision - A Quality Lifestyle, A Dignified Life)

You will have a voice inside and outside Parliament. Workers' Party puts pressure on the government to respond to your needs and opinions. The government needs to listen to the people. We make sure you are heard. (Our Beliefs > Why Support Us)
\end{abstract}

Other than the theme of providing citizens with an alternative political philosophy and voice, the WP presents itself as party that looks after the political, social and economic welfare of Singaporeans, particularly that of workers. The workers form a key element of the WP's identity. Table 2 lists the excerpts from which this theme is extracted.

Table 2: WP Represents the working class

\begin{tabular}{|c|c|c|}
\hline No. & Section of Website & Excerpt \\
\hline 2.1 & Our Organization - Our Logo & $\begin{array}{l}\text { "A yellow hammer. The hammer symbolizes workers and } \\
\text { yellow represents power of the people." } \\
\text { "The hammer is surrounded by a yellow ring, which stands } \\
\text { for unity of the workers of Singapore." }\end{array}$ \\
\hline 2.2 & $\begin{array}{l}\text { Our Organization - Constitution } \\
\text { and Rules - Objects }\end{array}$ & "To seek the unity of the Workers of Singapore." \\
\hline 2.3 & $\begin{array}{l}\text { Our Organization - Constitution } \\
\text { and Rules - Objects }\end{array}$ & $\begin{array}{l}\text { "To promote the political, social and economic and } \\
\text { emancipation of the people of Singapore and particularly of } \\
\text { the workers who depend directly on the exertion for their } \\
\text { livelihood." }\end{array}$ \\
\hline
\end{tabular}

Source: http://www.wp.org.sg/

Although the WP details its plans for Singapore in the areas of government, civil liberties, justice, law and order, economic policy, education, healthcare and public housing on its website, the WP has not been given the opportunity to put any of its proposed plans into action due to its limited presence in the parliamentary body. Pertaining to inter-group comparisons, the WP appears to contrast itself from the PAP in terms of its political ideology which is to provide Singaporeans "with the choice of voting for candidates with a different political philosophy from that of candidates put up 
by the ruling PAP" as choosing "rulers by a free vote in a Parliamentary election is the fundamental right of every citizen." Another inter-party difference claimed by WP is in the composition of its party members. The WP asserts that the PAP is run by an elite class and not by the people, which contrasts with what the WP says about its own identity, that of a party that represents the man on the street. The WP's criticism of what and who the ruling party stands for is clearly seen in the following:

\begin{abstract}
We speak as if the continuous pursuit of a higher standard of material living will essentially provide us with the meaning of life. The Singapore of today is run by an elite class and not by the people. (Our Beliefs > Vision - A Quality Lifestyle, A Dignified Life)
\end{abstract}

Where the PAP and the WP operate as a one-party political party, the SDA is a unique political entity by comparison as it is a coalition of four component parties. It must be noted that the SDA does not have a website of its own, and the party's webpages which communicate its history, vision and press releases are hosted on the website of the Singapore People's Party (one of the four member parties). The theme of the SDA as an alliance of opposition parties is an overarching one that pervades its website in sections such as "Homepage", "About SDA", Party Directions - Vision", "Press Kit" and "Members of SDA \& Links."

\footnotetext{
The SDA is an alliance of four component parties, namely - the Singapore People's Party (SPP), the National Solidarity Party (NSP), the Malay-based Pertubuhan Kebangsaan Melayu Singapura (PKMS) and the Singapore Justice Party (SJP). (Singapore Democratic Alliance $>$ About SDA)

Seven-member grouping set up to pool the resources of the two opposition parties for GE. Some members of two opposition parties that have joined forces to set up a civil society project that aims to pool their parties' information and resources for the coming General Elections. (Singapore People's Party > Press Releases)
}

As expressed in the above excerpts, the SDA exists as a coalition so that its component parties can effectively combine "resources to help build up a strong viable alternative political institution to challenge and compete with the PAP." The SDA frames its existence as the forging of a united opposition front so as to "gain maximum effectiveness in opposition politics" (see section titled "Party Directions - Vision"). Compared to both the PAP and the WP, the SDA is the youngest party having been established in 2001. Perhaps, due to its short history, there is no mention of party performance and inter-party comparison.

\title{
Unifying Political Themes but Diversified Framing Strategies
}

From the data gathered, the meta-codes reveal that despite different identity frames, all three parties frame political concepts in similar terms - "political culture", "equality", "the government" or "ruling party", "opposition parties", "citizenry" or "the people", and "quality of life." However, when referential content analysis was applied to examine the context in which the political concepts were found, the technique yielded interesting findings on how pertinent political concepts are framed differently by each party. Table 3 provides examples of key political concepts and how each code is deployed linguistically. 
Table 3: Referential analysis of key meta-codes

\begin{tabular}{|c|c|c|}
\hline$P A P$ & $W P$ & $S D A$ \\
\hline $\begin{array}{l}\text { Political culture } \\
\text { • Democracy (r) } \\
\text { "To safeguard the freedom, } \\
\text { and advance the well-being, } \\
\text { of Singaporeans through } \\
\text { representative and } \\
\text { democratic government" } \\
\text { • Choice (i.v.) } \\
\text { "The party of choice" } \\
\text { - Representative } \\
\text { (i.v.) } \\
\text { "Representative } \\
\text { government" } \\
\text { Strong mandate } \\
\quad \text { (i.v.) } \\
\text { seeking a strong } \\
\text { "PMandate in GE2006" } \\
\text { "Important for PAP to win } \\
\text { strong mandate" }\end{array}$ & 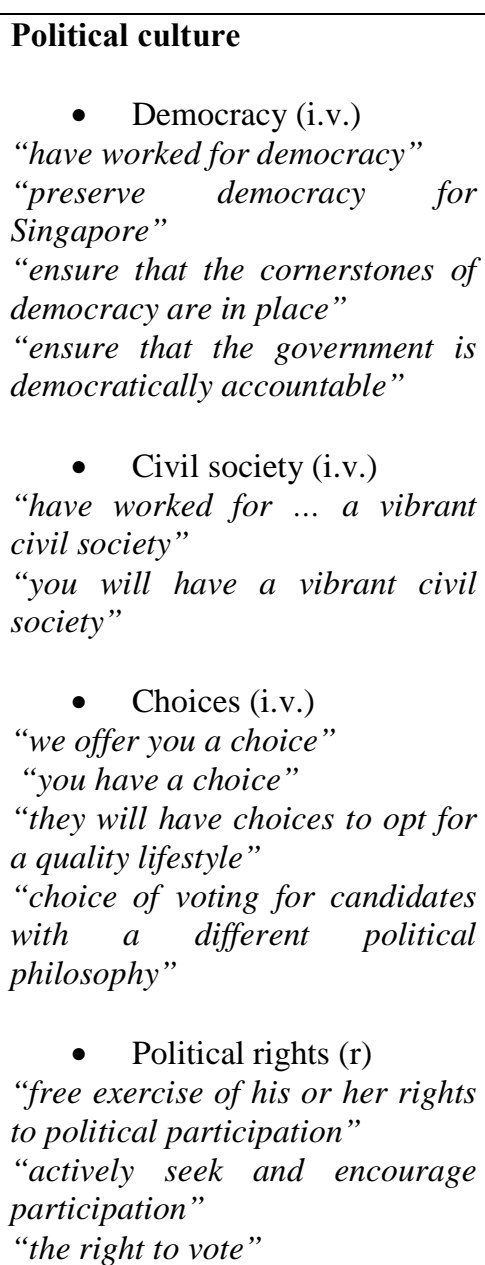 & $\begin{array}{l}\text { Political culture } \\
\text { • Democratic (i.v.) } \\
\text { "advance democratic growth of } \\
\text { Singapore's society" } \\
\text { "in a democratic country" } \\
\bullet \quad \text { Political competition (r) } \\
\text { "viable alternative political } \\
\text { institution to challenge and } \\
\text { compete with the PAP" } \\
\text { "strong opposition voice" } \\
\text { "people want to see competition" } \\
\text { • Rights (r) } \\
\text { "defend Singaporeans" rights and } \\
\text { interests" }\end{array}$ \\
\hline
\end{tabular}

i.v.: in vivo code

r: researcher code

From the referential analysis, it is evident that the three political parties frame key political concepts very differently, and their online discourse mirrors offline realities. The PAP highlights its successful and established history to garner Singaporeans' support in terms of a strong mandate during election times. The concept of "choice" is used in adjectival form which communicates that the PAP is the party of people's choice, a claim that is supported by its unchallenged success over all past elections. Codes that emerged from the data such as "moving ahead", "brighter future" and "better life" echo the theme of the PAP being the people's provider, and emphasize the PAP's offline track record of economic deliverables. The online discourse clearly reiterates that the government, formed by the PAP, is effective and progressive. In its website discourse, the PAP describes the "opposition" as ineffective and lacking in vision and ideas. This echoes a finding mentioned in the earlier section on the PAP's inter-party comparisons 
where the PAP contrasts the party's claimed track of tangible results with opposition parties' abstract campaign platforms (i.e. "democracy", political rights" and "choices").

Table 3: Referential analysis of key meta-codes (cont.)

\begin{tabular}{|c|c|c|}
\hline$P A P$ & $W P$ & $S D A$ \\
\hline $\begin{array}{l}\text { Equality for all } \\
\text { • Equal (i.v.) } \\
\text { "To create a vibrant, just and } \\
\text { equal society" } \\
\text { "equal treatment in education, } \\
\text { housing and health" } \\
\text { • Singaporeans (i.v.) } \\
\text { "wherever Singaporeans go, } \\
\text { they feel proud" } \\
\text { "Singaporeans should not } \\
\text { short-change themselves by } \\
\text { voting the opposition" } \\
\text { • Race and religion (r) } \\
\text { "regardless, of race, language } \\
\text { or religion" } \\
\text { "belonging to different races } \\
\text { and religions" } \\
\text { • Minorities (i.v.) } \\
\text { "minorities are assured of } \\
\text { proportionate representation" }\end{array}$ & $\begin{array}{l}\text { Citizenry } \\
\text { • People } \\
\text { "gave much hope for the people" } \\
\text { "in ensuring that you, the people, } \\
\text { are heard" } \\
\text { "represents power of the people" } \\
\text { • Singaporeans (i.v.) } \\
\text { "Singaporeans will be hard hit" } \\
\text { • Workers (i.v.) } \\
\text { "unity of the workers of } \\
\text { Singapore" }\end{array}$ & $\begin{array}{l}\text { Citizenry } \\
\text { • People (i.v.) } \\
\text { "people of Singapore" } \\
\text { "interests of the people" } \\
\text { - Singaporeans (i.v.) } \\
\text { "for the benefit of all } \\
\text { Singaporeans" } \\
\text { "Singaporeans will be proud of" } \\
\text { "Singaporeans' rights" } \\
\text { • Society (i.v.) } \\
\text { "making an impact on the } \\
\text { society" }\end{array}$ \\
\hline
\end{tabular}

As another example, "equality" is defined and framed by the PAP in economic terms, e.g. the opportunities given to people from different religious and racial backgrounds to have a good life. This is sharply contrasted with how the same political concept takes on an ideological dimension when used by the opposition parties who equate equality with political rights. On the other hand, both the WP and the SDA frame key political concepts very differently from the PAP. First, as seen in Table 3, the political codes that emerged more frequently fall under the meta-code of "political culture" for both the WP and the SDA. A stark difference between the PAP and the WP is how the two parties use the word "choice." Where the PAP claims that it is the party of "choice" (used in the adjectival form), one of the main messages extracted from the WP's web discourse is how the opposition party fights to provide Singaporeans with "choices" (used as a noun). Themes such as "civil society" and "rights" are completely absent from the PAP's web discourse. In stark contrast with the tangible gains that the PAP offers to Singaporeans, it appears that the WP offers intangible benefits such as political choices and citizenry rights to a more democratic political system. Not only does this rhetorical strategy reinforces the WP's identity as an opposition party that champions democratic rights, it 
also contrats with the PAP's dominant offline rhetoric on the tried and tested effectiveness of Singapore's one-party system.

Through a simple word count, another difference that emerges is that codes related to political culture like "democracy" and "democratic" occur at a much higher frequency on the WP and SDA websites than on the PAP website. "Democratic" is used as an adjectival form to describe the desired state of the Singapore political system that the SDA wants to work towards toward. The SDA frames the PAP as a competitor it is standing up against. Unlike the PAP which uses the code "opposition" in a negative way, the WP's and the SDA's common assertion is that a strong opposition is essential for a politically healthy and desirable system that will lead to quality life for the citizenry.

Table 4: Website functionality

\begin{tabular}{|l|l|l|l|}
\hline Website Functionality & PAP & WP & SDA \\
\hline $\begin{array}{l}\text { Transparency and } \\
\text { information provision }\end{array}$ & 13 & 10 & 4 \\
\hline Interactivity and & 18 & 1 & 1 \\
\hline Networking & 5 & 1 & 2 \\
\hline $\begin{array}{l}\text { Presentation } \\
\text { delivery }\end{array}$ & 15 & 9 \\
\hline
\end{tabular}

\section{Online Structural Features}

As noted in the literature review above, scholars who describe the Internet as a leveling tool for marginalized groups typically focused on Internet features, such as how websites can be used to recruit supporters and enhance political participation (e.g. Cunha, Martin, Newell and Ramiro, 2003; Gibson and Ward, 1998; Margolis, Resnick and Levy, 2003). This section of the paper examines the structural features of the PAP, WP and SDA websites to explore if and how latent features contribute to any equalizing effect of the Internet. For the purpose of analyzing the websites, the coding scheme developed by Gibson and Ward (2003) was adapted to measure the levels of transparency and information provision, interactivity, networking, and presentation and delivery. The assumption is that the ability to use these four components on the websites has implications on how the Internet can enhance a party's ability to reach a broader audience and assume a more prominent position in the political playing field (Gibson and Ward, 2003). Table 4 shows the summary of scores per website for each component (see Appendix A for the coding categories and detailed scoring for each website).

The findings indicate that the PAP achieves the highest score for all components except for networking. Compared to the opposition parties, in particular the SDA, the PAP is the most effective in using the Internet to disseminate information about its policies, agenda and party activities, provide space so for members of the public to interact with one another and with PAP members (through the P65 Blog and the Young PAP forum), and appeal to website visitors who visit the website through interactive 
features (such as ----?). The PAP has a lower score compared to the SDA in terms of networking features as the website only features partisan links to other groups that support the party's goals (e.g. Young PAP and PAP Women's Wing), whereas the SDA website features links to neutral sites (e.g. non-governmental organizations like the Think Centre) in addition to partisan sites. Findings from an earlier study by Soon and Kluver (2007) suggest that the PAP's lack of online associations with other organizations may be a reflection of its consolidated and unchallenged political position in the real world.

The Internet has been described as having the potential to provide marginalized groups like Singapore's opposition parties with opportunities to bypass constraints such as regulations and high costs present in traditional media, but this study suggests that the WP and the SDA do not take advantage of the intrinsic features of the Internet to disseminate party information, promote interaction with the public and generate civic discourse. This is especially evident in the case of the SDA whose website scored the lowest for three out of the four components measured.

\section{Conclusion}

\section{De-equalizing effects of normalizing Rhetoric}

The historical, regulatory and financial constraints that exist in the offline context limit both the ability of Singapore opposition parties' to promote themselves and recruit supporters for their political cause, as well the scope of their campaigning platform. Previous research by Gibson and Ward (1998), and Margolis et.al. (2003) suggested that the Internet, which affords instant global reach and low costs of set-up and management, provides minor parties with opportunities to equalize the political playing field. Cunha, Martin, Newell and Ramiro (2003) suggested that strong possibilities avail in the age of new information communication technologies for "party-competition leveling." Their analysis of European political parties demonstrated that the Internet equalizes opportunities for both major and minor southern European parties by bridging the parties with the electorate and engendering opportunities for citizenry participation. However, this study suggests that normalizing rhetoric and the under-utilization of online structural features by marginalized political parties may actually limit such party-competition leveling. In this paper, I argue that the equalizing potential of the technology is normalized, both by the narrative structures adopted by political parties in their online discourse and the way political parties exploit latent features of the Internet, resulting in the reinforcement of unbalanced pre-existing party relations.

Three themes emerged from the analysis of the narrative structures adopted by the three political parties - role of the party, party performance and inter-party differences. The parties framed their identities through narratives of their past, their political history set against Singapore's survival during post-colonial times, what they stand for, and what their vision and goals are. The narrative structures also center on how the parties framed their achievements (or lack thereof) in the past and what they hope to accomplish for Singaporeans and the nation in the future. However, this paper proposes that the narrative structures adopted by the opposition parties highlighted their weaknesses as the narratives highlight the lack of party performance in the real world. This is particularly visible in the 
case of the SDA which provides little information at all concerning its vision and plans for Singapore should it come into power. On the contrary, given its claims to success in guiding Singapore from a vulnerable situation during post-colonial times to its current position in the global marketplace, the three-prong narrative structure appears to work to the advantage of the PAP because it reinforces its successful track record and its powerful image of being the nation's provider and protector.

\section{Under-Mobilization of Structural Features}

In addition to the rhetorical style and narrative structure that resulted in a normalizing effect on party image and relations, how each party exploits the features of the Internet further reinforced the de-equalizing effects. Scheider and Foot (2002) found that in the American context, all 13 campaign sites included candidate biographies, campaign news and position papers, and nearly all the sites analyzed included video or audio clips, campaign speeches and opportunities to subscribe to email newsletters. The structural features of the websites also facilitated campaign participation activities such as citizen feedback and volunteer sign up. In the Singapore context, the ruling party appears to be the only party able to utilize its party website as an information-provision and recruitment tool. The PAP rhetoric decribing itself as an effective leader of the nation is reinforced online by the contemporary presentation and interactive features of its website, which enable members of the public to interact with one another as well as with PAP members. The PAP website also scored the highest in terms of content presentation and delivery. On the contrary, although both the WP and the SDA profess that one of their party objectives is to foster a more vibrant political environment through generating alternative voices, their websites are devoid of features that provide visitors with structural features that would allow them to take part in political discussions. Compared to the PAP website, the WP and SDA websites appear to under-utilize structural features in three areas - to improve transparency and information provision, interactivity and presentation and delivery.

Based on the findings, this study questions the technologically deterministic perspective on how the Internet levels the political playing field and leads to greater democratization of societies. The findings suggest that the equalizing effect of the Internet is not only dependent on its inherent technological characteristics, but also on website discourse and the deployment of structural features. In the case of Singapore's political parties, normalizing rhetoric appears to reinforce instead of challenge existing imbalances in power, and diminishes the equalizing potential of the Internet. One limitation of this study is that it did not take into account other factors such as intra-party politics (in the case of the SDA) or lack of funds and expertise which may have accounted for the poorly designed websites. Such considerations may provide some insights into why political parties like the SDA have weak online presence. A direction for future studies is to investigate the intent and motivations of website developers through techniques such as interviews to further understand the role of party websites. Given the nature of politics in Singapore, another limitation of this study is that the sample is limited to only three political parties. This limitation can be overcome in replicating the study in countries with more vibrant political intercourse and where minor 
political parties play a more visible role in shaping political discourse and governance, thereby yielding a larger sample.

The political culture in Singapore could have played a debilitating role in limiting the mobilization and equalization effects of the Internet. Kalathil and Boas (2003) hypothesized that the democratizing and liberating effects of the Internet can be curbed through a combination of reactive and proactive strategies in closed regimes. However, in recent years, developments in the media regulatory landscape point to possible transformations in the role of Internet technologies. The growing use of new media for self-expression and the sharing of opinions (e.g. in the case of blogs) have spurred the government's recognition of new media's potential to change the political landscape. In his analysis of the use of new media technologies like blogs, podcasts and instant messaging systems during the 2005 Presidential election, Kluver (2007) concluded that the Internet is broadening the scope of civic discussion in Singapore by enabling the public to engage in issues of political and social significance in "non-politicized forums" (p.19). Demonstrating a mindset change, the government acknowledged how new media has changed politics in countries like the U.S., China, South Korea and Malaysia, and alluded to the impending easing of regulations that govern new media use in Singapore (Chia, 2008). Some of the measures that the government is exploring include permitting Singaporeans to post political videos and campaign material on the World Wide Web by the next general election in 2011 , and reexamining the existing ban on the dissemination of party political films and on outdoor demonstrations. In addition to proposing different approaches to understanding the mobilizing potential of the Internet, this paper calls for future research that investigates the dynamics between changing political cultures, the Internet and political mobilizing opportunities in Asian contexts. 


\section{References}

Abbott, Jason P. 2001. Democracy@internet.asia? The challenges to the emancipatory potential of the net: Lessons from China and Malaysia. Third World Quarterly 22(1): 99-114.

Anderson, David M., and Michael Cornfield. 2003. The civic web: online politics and democratic values. Lanham, MD: Rowman \& Littlefield.

Banerjee, Indrajit. 2002. The locals strike back? Gazette: The International Journal for Communications Studies 64(6): 517-535.

Bimber, Bruce. 1999. The Internet and citizen communication with government: Does the medium matter? Political Communication 16(4): 409-429.

Castells, Manuel. 2004. The power of identity. Malden, Mass.: Blackwell Publishing.

Chia, Sue-Ann. 2008. Political videos on Net for next GE. The Straits Times, August 19, pp. A4.

Coffey, Amanda, and Paul Atkinson. 1996. "Concepts and Coding," In Making Sense of Qualitative Data: Complementary research strategies, ed. Amanda Coffey \& Paul Atkinson, 26-53. Thousand Oaks: Sage Publications.

Cunha, Carlos, Irene Martin, James Newell, and Luis Ramiro. 2003. Southern European parties and party systems, and the new ICTs. In Political parties and the Internet: Net gain?, ed. Rachel K. Gibson, Paul Nixon \& Stephen Ward, 70-97. London: Routledge.

Davis, Richard, and Diana Owen. 1998. New media and American politics. New York: Oxford University Press.

Della Porter, Donatella, and Mario Diani. 2006. Social movements: an introduction. Malden, MA: Blackwell.

Dertouzos, Michael. 1997. What will be: How the new information marketplace will change our lives. San Francisco: Harper.

Diani, Mario. 2000. Social movement networks virtual and real. Information, Communication \& Society 3(3): 386-401.

Garrido, Maria, and Alexander Halavais. 2003. Mapping networks of support for the Zapatista. In Cyberactivism: Online activism in theory and practice, ed. Martha McCaughey \& Michael D. Ayers, 145-164. New York: Routledge.

Gibson, Rachel, and Stephen J. Ward. 1998. U.K. political parties and the Internet: "Politics as usual" in the new media?" The Harvard Journal of Press \& Politics 3(2): 14-38.

Gomez, James. 2002. Internet politics: Surveillance and intimidation in Singapore. Singapore: Think Centre.

Gurak, Laura, and John Logie. 2003. Internet protests from text to web. In Cyberactivism: Online activism in theory and practice, ed. Martha McCaughey \& Michael D. Ayers, 25-46. New York: Routledge.

Hill, Kevin, and John E. Hughes. 1998. Cyberpolitics: Citizen activism in the age of the Internet. Lanham, MD: Rowman \& Littlefield Publishers, Inc.

Ho, Kuan Chong, Zaheer Baber, and Habibul Khondker. 2002. 'Sites' of resistance: alternative websites and state-society relations. British Journal of Sociology 53(1): 127-148. 
Infocomm Development Authority of Singapore. Annual Survey on Infocomm Usage in Households and by Individuals for 2006. http://www.ida.gov.sg/doc/Publications/Publications_Level2/20061205092557/hh06 _public_v4.4.pdf (accessed June 1, 2007)

Jenkins, Henry. 2006. Fans, bloggers and gamers: Exploring participatory culture. New York: New York University Press.

Kalathil, Shanthi, and Taylor C. Boas. 2003. Open networks, closed regimes. Washington, DC: Carnegie Endowment for International Peace.

Kluver, Randy. 2007. The Internet and the expansion of political discussion in Singapore elections. Paper presented at International Communication Association conference, May 24-28, in San Francisco, CA, U.S.

Kluver, Randy, and Indrajit Banerjee, I. 2005. The Internet in nine Asian nations. Information, Communication \& Society 8(1): 30-46.

Koh, Winston, and Kam Wong Poh. 2005. Competing at the frontier: The changing role of technology policy in Singapore's economic strategy. Technological Forecasting \& Social Change 72: 255-285.

Lessig, Lawrence. 1999. CODE and other laws of cyberspace. New York: Basic Books.

Liu, Dejun. (1999). The Internet as a mode of civic discourse: The Chinese virtual community in North America. In Civic discourse, civil society, and Chinese communities, ed. Randy Kluver and John H. Powers, 195-208. Connecticut: Ablex Publishing Corporation.

Margolis, Michael, David Resnick, and Johnathan Levy. 2003. Major parties dominate, minor parties struggle: US elections and the Internet. In Political parties and the Internet: Net gain?, ed. Rachel K. Gibson, Paul Nixon \& Stephen Ward, 53-69. London: Routledge.

Murdock, Graham, and Peter Golding. 1989. Information poverty and political inequality: Citizenship in the age of privatized communications. Journal of Communication 39: 180-193.

Negroponte, Nicholas. (1995). Being digital. New York: Knopf.

Norris, Pippa. 2000. A virtuous circle. Cambridge: Cambridge University Press.

Norris, Pippa. 2002. Democratic phoenix. Cambridge: Cambridge University Press.

Paolino, Philip, and Daron R. Shaw. 2003. Can the Internet help outsider candidates win the presidential nomination? Political Science and Politics 36(2): 193-197.

Park, Han Woo. 2003. Hyperlink network analysis: A new method for the study of social structure on the web. Connections 25(1): 49-61.

Polletta, Francesca, and James M. Jasper. 2001. Collective identity and social movements. Annual Review of Sociology 27:83-305

Porter, David. 1997. Internet culture. United Kingdom: Routledge.

Poster, Mark. 1997. Cyberdemocracy - Internet and the public sphere. In Internet culture, ed. David Porter, 201-218. United Kingdom: Routledge.

Resnick, David. 1997. Politics on the Internet: The normalization of cyberspace. New Political Science 41-42: 47-67.

Rodan, Garry. 1998. The Internet and Political Control in Singapore. Political Science Quarterly 113(1): 63-89.

Rodan, Garry. 2003. Special issue on electronic media, markets and civil society in East and Southeast Asia: Introduction. The Pacific Review 16(4): 455-464.

18 | Journal of Contemporary Eastern Asia, Volume 9, No.1 
Rogers, Richard, and Nootje Marres. 2000. Landscaping climate change: A mapping technique for understanding science and technology debates on the World Wide Web. Public Understanding of Science 9(2): 1-23.

Ryan, Gery, and H. Russell Bernard. 2003. Techniques to Identify Themes. Field Methods 15(1): 85-109.

Schneider, Steven, and Kirsten Foot. 2002. Online action for political action: Exploring presidential campaign web sites from the 2000 American election. Javnost The Public 2(5): 1-17.

Schwartz, Ed. 1996. Netactivism: How citizens use the Internet. Sebastapol, CA: Songline Studios, Inc.

Shapiro, Andrew. 1999. The Control Revolution. New York: PublicAffairs.

Soon, Carol, and Randolph Kluver. (2007). The Internet and online political communities in Singapore. Asian Journal of Communication 17(3): 246-265.

Stein, Laura. 2007. National social movement organizations and the World Wide Web: A survey of web-based activities and attributes. Paper presented at International Communication Association conference, May 24-28, in San Francisco, CA, U.S.

Stromer-Galley, Jennifer, and Kirsten Foot. 2002. Citizen perceptions of online interactivity and implications for political campaign communication. Journal of Computer-Mediated Commuication, 8(1). http://www.ascusc.org/jcmc/vol8/issue1/stromerand foot.html (accessed July 23, 2003)

Tan, Tarn How 2002. Probe in Web articles spook Net community. The Straits Times, July 6 , pp. H2.

Tremayne, Mark. 2007. Blogging, citizenship, and the future of media. New York: Routledge.

Vegh, Sandor. 2003. Classifying forms of online activism - The case of cyberprotest against the World Bank. In Cyberactivism: Online activism in theory and practice, ed. Martha McCaughey \& Michael D. Ayers, 71-95. New York: Routledge.

Ward, Stephen, Rachel Gibson, and Paul Nixon. 2003. Introduction. In Political parties and the Internet: Net gain?, ed. Rachel K. Gibson, Paul Nixon \& Stephen Ward, 110. London: Routledge.

Ward, Stephen, Rachel Gibson, and Paul Nixon. 2003. Parties and the Internet. In Political parties and the Internet: Net gain?, ed. Rachel K. Gibson, Paul Nixon \& Stephen Ward, 11-38. London: Routledge.

Warnick, Barbara. 2001. Rhetorical criticism in new media environments. Rhetoric Review 20: 60-65. 


\section{APPENDIX A: FEATURE ANALYSIS}

1. Transparency and information provision (1 point each)

\begin{tabular}{|l|l|l|l|}
\hline Item & PAP & WP & SDA \\
\hline 1. Organizational history & 1 & 1 & 1 \\
\hline 2. Structure & 1 & 1 & 0 \\
\hline 3. Values/Ideology & 1 & 1 & 1 \\
\hline 4. Policies & 1 & 0 & 0 \\
\hline 5. Documents (manifesto, constitution etc) & 1 & 1 & 0 \\
\hline 6. Newsletters & 1 & 1 & 0 \\
\hline $\begin{array}{l}\text { 7. Media releases (i.e. speeches, statements, interview transcripts, } \\
\text { conferences) }\end{array}$ & 1 & 1 & 1 \\
\hline 8. People/Who's who & & \\
\hline 9. Leader focus (picture, text on home page) & 1 & 1 & 0 \\
\hline 10. Candidate profiles & 1 & 0 & 1 \\
\hline 11. Electoral information (Statistics, information on past performance) & 0 & 1 & 0 \\
\hline 12. Event calendar (prospective or retrospective) & 1 & 0 & 0 \\
\hline 13. Conference information & 0 & 0 & 0 \\
\hline 14. FAQs & 0 & 1 & 0 \\
\hline 15. Privacy policy & 0 & 0 & 0 \\
\hline 16. Article archive or library & 1 & 0 & 0 \\
\hline 17. Group pages & 1 & 0 & 0 \\
\hline Total & $\mathbf{1 3}$ & $\mathbf{1 0}$ & $\mathbf{4}$ \\
\hline
\end{tabular}

2. Interactivity (1 point each)

\begin{tabular}{|l|l|l|l|}
\hline Item & PAP & WP & SDA \\
\hline 1. Information gathering (1) & 1 & 0 & 0 \\
\hline 2. Information gathering (2) & 1 & 0 & 0 \\
\hline 3. Talking about politics with friends & 1 & 0 & 0 \\
\hline 4. Trying to influence others' opinions & 0 & 0 & 0 \\
\hline 5. Advertising & 0 & 0 & 0 \\
\hline 6. Leafleting & 0 & 0 & 0 \\
\hline 7. Contacting & 1 & 1 & 0 \\
\hline 8. Petitioning & 0 & 0 & 0 \\
\hline 9. Dialogue & 1 & 0 & 0 \\
\hline 10. Donating & 0 & 0 & 0 \\
\hline 11. Joining (associate) & 0 & 0 & 1 \\
\hline 12. Joining (full) & 0 & 0 & 0 \\
\hline 13. Campaigning & 0 & 0 & 0 \\
\hline 14. Membership section & 0 & 0 & 0 \\
\hline Total & $\mathbf{5}$ & $\mathbf{1}$ & $\mathbf{1}$ \\
\hline
\end{tabular}


3. Networking (1 point each)

\begin{tabular}{|l|l|l|l|}
\hline Item & PAP & WP & SDA \\
\hline Internal & & & \\
\hline 1. Federal party & 0 & 0 & 0 \\
\hline 2. Federal party leader home page & 0 & 0 & 0 \\
\hline 3. State parties & 0 & 0 & 0 \\
\hline 4. Local parties & 0 & 0 & 0 \\
\hline External & & & \\
\hline 1. Partisan links to other parties and organizations & 1 & 1 & 1 \\
\hline 2. Reference links to neutral or news/educational sites & 0 & 0 & 1 \\
\hline 3. Commercial links to those promoting business services & 0 & 0 & 0 \\
\hline Total & $\mathbf{1}$ & $\mathbf{1}$ & $\mathbf{2}$ \\
\hline
\end{tabular}

4. Presentation and delivery (1 point each, except for items under "Freshness")

\begin{tabular}{|c|c|c|c|}
\hline Item & $\begin{array}{l}\mathbf{P} \\
\mathbf{A} \\
\mathbf{P}\end{array}$ & $\begin{array}{l}\mathbf{W} \\
\mathbf{P}\end{array}$ & $\begin{array}{l}\mathbf{S} \\
\mathbf{D} \\
\mathbf{A}\end{array}$ \\
\hline \multicolumn{4}{|l|}{ Glitz factor } \\
\hline 1. Graphics & 1 & 1 & 1 \\
\hline 2. Frames & 1 & 1 & 0 \\
\hline 3. Moving icons & 1 & 0 & 1 \\
\hline 4. Sound & 0 & 0 & 0 \\
\hline 5. Video & 0 & 0 & 0 \\
\hline 6. Live streaming & 0 & 0 & 0 \\
\hline \multicolumn{4}{|l|}{ Access } \\
\hline 1. No-frames option & 0 & 0 & 0 \\
\hline 2. Text-only option (entire site) & 0 & 0 & 0 \\
\hline $\begin{array}{l}\text { 3. Text-only documents to download and print (clearly listed as } \\
\text { such) }\end{array}$ & 0 & 0 & 0 \\
\hline 4. WAP/PDA 'wireless' enabled & 0 & 0 & 0 \\
\hline 5. Foreign language translation & 0 & 0 & 0 \\
\hline 6. Software for the blind/visually impaired & 0 & 0 & 0 \\
\hline 7. Size of homepage in $\mathrm{Kb}(>25$ slows site loading time $)$ & 1 & 1 & 1 \\
\hline \multicolumn{4}{|l|}{ Navigability } \\
\hline 1. Navigation tips & 0 & 0 & 0 \\
\hline 2. No. of search engines & 1 & 0 & 0 \\
\hline 3. Home-page icon in lower-level pages & 1 & 1 & 1 \\
\hline 4. Fixed menu bar on lower-level pages & 1 & 1 & 1 \\
\hline 5. Site map/index & 0 & 0 & 0 \\
\hline \multicolumn{4}{|l|}{ Freshness } \\
\hline 1. Ordinal index (0-6) & 5 & 4 & 1 \\
\hline 2. Updated (0-6) & 6 & 6 & 3 \\
\hline Total & 18 & 15 & 9 \\
\hline
\end{tabular}

